\title{
A Comparative Study of the Elements of Narrative Technique in the English Translation of Tolstoy's The Death of Ivan Ilyich and Chekhov's The Grasshopper
}

\author{
By Jacqueline Carr-Phillips*
}

The aim of the paper is to examine the elements of narrative technique in Tolstoy's long story The Death of Ivan Ilyich, in the context of a comparative study of Anton Chekhov's short story The Grasshopper. I will be discussing the underlying narrative strategies that highlight the distinctive features of laconicism and restraint that Chekhov employs in his writing to allow for deeper configurations of meaning through the implicit dimension of language. In parallel to this I will explore the effectiveness of Tolstoy's use of the explicit dimension of language to convey meaning, purpose and emotional impact as told directly with substantial descriptive passages. I will also attempt to identify implicit aspects of Tolstoy's narrative that are embedded in the explicit text, to uncover a deeper meaning to the direct "telling" of the surface story. The paper is not attempting to favour one style over the other in order to demonstrate the authors' effectiveness in conveying meaning and purpose through explicitness or implicitness. Rather, it is a study of the contrasting individuality of the two literary writing styles as seemingly opposite to each other in relation to the elements of narrative technique that are being used to shape the story. The intention is to demonstrate a parallel effectiveness in the two contrasting forms to convey the vision of the story through the shaping of the narrative. The context in which these particular writers are discussed is directly related to the technical concerns and compositional poetics that the writer employs for the creation of the story, whether it be a Chekhovian capturing of fleeting moments, sense impressions and minimalism or a more rounded Tolstoyan detailed, explicit depiction.

\section{Introduction}

Leo Tolstoy and Anton Chekhov are very different writers. The paper explores these differences to show how they ultimately achieve the same outcome, in terms of the crafting of a short story.

Tolstoy favoured exposition and detailed description in his work, often in minute detail through an external omniscient narrator. His stories are generally highly plotted with a beginning, middle and rounded out conclusion. A discernable moral message usually pervades his narratives, often with substantial philosophical digression via authorial comment, or through his characters. Richard Freeborn points out that the long short story serves as a suitable vehicle for Tolstoy as it "can demonstrate more directly the purpose of his art as a vehicle for infecting the reader with the author's feelings" (Freeborn 2002: 127).

Chekhov, on the other hand, favoured brevity and restraint, avoiding any overt moral message. He shunned sentimentality and preferred laconicism and restraint to an explicitly detailed text, advising his brother, Aleksandr, to be wary of embellished language: "Beware of precious language. Language should be simple and elegant" (McVay 2001: xx). His stories are methodically shaped according to, as Tobias Wolff puts it "his instinct for the essential and his impatience with the inessential" (Wolff 1988: xiv). He disliked excessive

\footnotetext{
*Trustee and Vice Chair, Maharishi International Graduate School, UK.
} 
exposition and superfluous adjectives, "Cross out as many adjectives and adverbs as you can", he advised Gorky (Wolff 1988: xiv).

In this regard Chekhov was ruthless, he offered similar advice to other writers, to cut back, to simplify the narrative to its essence. He went on to further advise Gorky:

Your only shortcoming is a lack of restraint, a lack of grace. Grace is when a person spends the minimum amount of energy to achieve a particular effect. Your expenditure is patently excessive ... Your descriptions of nature are artistic ... but the frequent comparisons with human beings (anthropomorphism), when the sea breathes, the sky gazes, ... make the descriptions rather monotonous, sometimes sugary, sometimes vague. Vividness and expressiveness in nature descriptions can be achieved only by simplicity ... (McVay 2001: xxi).

Chekhov creates social and moral commentary without actually writing about it. In other words he withdraws himself, as author narrator, from any emotional attachment to the story, as Chekhov himself put it when writing to his brother:

... One has to be indifferent when writing sad stories ... One can weep and groan as one writes, and suffer along with one's heroes, but I think one should do so without the reader noticing. It makes a more powerful impression the more objective one is ... . The more emotional a scene is, the more coldly one should write, and the more powerful will be the emotional effect. One shouldn't coat things with sugar ... (McVay 2001: xx-xxi).

In contrast Tolstoy writes explicitly and specifically, often didactically, to the point of preaching his views on moral and religious issues. Andrew Barger remarks that "at times he can be overhanded in doling out his agenda; preachy almost ..." (Barger 2009: 10).

The Death of Ivan Illyich is an exception in that the explicit details given in this story are not directly revealing the implicit meaning beneath the text, which actually has a moral purpose. Unusual for Tolstoy, the moral purpose remains unexpressed and is therefore more powerfully rendered. It is as if Tolstoy is following Chekhov's advice to write coldly, without emotional engagement, and it is this that allows the implicit dimension to be maintained throughout the narrative, without directly referring to the essence of the story.

My decision to foreground Chekhov's story, The Grasshopper, instead of selected extracts from several of his stories, is because I found it to be an increasingly compatible example to study alongside Tolstoy's story as I was working through it. Although the two literary styles retain their contrasting individuality, according to the elements of narrative technique used to shape their stories, there are identifiable short story features to be found in The Death of Ivan Illyich along with a number of overlapping tendencies, in terms of narrative features, that bring the two stories closer together as suitable for this study. 


\section{Narrative Features and Comparative Study}

An example of a short story feature that is most remarkable in Tolstoy's story is demonstrated by its achievement of the "single effect". Edgar Allen Poe, the first to theorise the short story as a self conscious genre, considered the "single effect" or "unity of effect" to be of prime importance and that this could only be experienced in works that could be read "at one sitting" (Poe 2003: 432).

If any literary work is too long to be read at one sitting, we must be content to dispense with the immensely important effect derivable from unity of impression ... the whole thing being deprived, through the extremities of its length, of the vastly important artistic element, totality, or unity of effect (Poe 2003: 432).

Of the "single effect" Charles E. May, refers to the origins of the short story being "as old as the primitive realm of myth" (May 2002: 1). He does, however, recognise that there is some justification for the common claim of its beginnings as a distinct literary genre in the nineteenth century, but at the same time noting that the first ancient stories were "brief episodic narratives" (May 2002: 1) constituting the basis of the modern short story form:

In many ways the short story, with its usual focus on a single event and a single effect, has remained close to its primal mythic source. Philosophic anthropologist Ernst Cassirer, echoes Poe's famous delineation of the short story's singleness of effect in his description of mythical thinking, which he asserts, also focuses all forces on a single point: "It is as though the isolated occurrence of an impression, its separation from the totality of ordinary, commonplace experience produced not only a tremendous intensification, but also the highest degree of condensation" (May 2002: 1).

This "intensity of impact" resulting from the "single effect", that Poe considered to be a vital feature of the short story form, cuts like a knife through the narrative of The Death of Ivan Illyich. The explication is consistently sharp, graphic, and focused in the experience of the physical and mental torments that Ivan suffers prior to his death. As Richard Freeborn puts it, "The tone of the narrative is steely and relentless" (Freeborn 2002: 130).

Poe points out that the importance of the "single effect", is not only essential in connection with the way a story begins, but also in the consistent application of it throughout the narrative:

If his very first sentence tend not to the outbringing of this effect, then in his very first step he has committed a blunder. In the whole composition there should be no word written of which the tendency, direct or indirect, is not to the one preestablished design (Poe 2003: 396).

The single idea, however, is not just about Ivan's sufferings during his illness, but also in the details about his life leading to his untimely death. The two are inextricably linked and remarkably do not deviate from the single focus of the story. Where this story deviates from Poe's theories of the short story is in the use of the omniscient, external narration throughout the narrative, but 
even this does not distract from the single effect. The intensity of impact is maintained throughout by the tone and focused attention of the narrator, without distraction into side commentaries of a clear-cut moral stance.

Like Chekhov, Poe criticised the writers of short stories who, in their construction of a story included too much detail through description, dialogue or authorial comment. He considered this to be mere embellishment resulting in a dilution of interest, rather than the precise crafting of the "single effect".

It is interesting to note how The Death of Ivan Ilyich breaks away from Tolstoy's usual novelistic approach to the writing of short fiction, despite the use of considerable description and explication. He achieves the "single effect" in this story by offering the reader a direct experience of Ivan's life and demise step by step, without deviation, that ultimately allows the reader to not only sense, but also to "feel" his pain and anguish, as the following extract shows:

Tolstoy dwells on the day-to-day detail of Ivan Ilyich's existence, slowing the action down to make us share his agony hour by hour. At times the narration moves from the past into the present tense to increase the immediacy of our involvement (Cook 2004: xviii).

In parallel to this the narrator maintains a tone of cool, uninvolved commentary on the struggles that Ivan is experiencing with his pain, debilitating symptoms and loss of control. Even expressing at times a slightly amused and matter of fact view of the situation, implying that Ivan brought it all on himself and this is the natural outcome of such a self-absorbed concern with right behavior and status. The awfulness of this emotional distancing of Ivan's sufferings, and the possible cause of it, has the effect of increasing the reader's sympathy in tandem with the experience of living through the misery with him.

Tobias Wolff points to Tolstoy's usual treatment of short fiction, generally proceeding with the same novelistic pace and development that he employs in his novels:

Tolstoy, whose work Chekhov admired, even to the point of reverence, came to short fiction with the impulse of the novelist. His stories have discernable beginnings in which the characters are introduced and the situation set forth, middles in which the characters are tested by the developing situation and endings that resolve these complications, with rich satisfying finality ... His conclusions are not intended to release the mind into avenues of possibility but rather to teach particular truths (Wolff 1988: xiii-xiv).

Where this story differs is in its development. It reads as a seamless continuum that is not highly plotted or sectioned into a clear beginning, middle and ending. The focus is on one idea without deviation, thus creating the single effect that Poe identifies as a significant feature of the short story form. The conclusion differs too, despite its tone of finality, as there is no direct authorial comment regarding a moral message.

Poe's theory of the single unified effect in the short story form has endured over time. Many twentieth century and contemporary writers have alluded to 
Poe's theory directly and indirectly in their own words. For example, in comparing the novel and short story form, Frank O'Connor writes:

... the element of time is his greatest asset, the chronological development of character or incident is essential form as we see it in life ... For the short story writer there is no such thing as essential form ... it is organic form, something that springs from a single detail and embraces past, present and future (O'Connor 2003: 7).

More recently, in the Guardian Review, Melissa Harrison reviews Chris Power's debut collection of short stories, Mothers, and quotes from an essay that Power wrote on American novelist and short story writer, James Salter. In this quote Power appears to be giving a nod to Poe's "single effect", compared with the cumulative narrative found in the novel form: He writes that the short story "prioritises the extraordinary moment above the changes over time found in novels" (Harrison 2018: 28).

The Death of Ivan Illyich opens with what would generally be considered to be its end: the immediate aftermath of Ivan's death. At the Law Courts, Ivan's colleagues are discussing a case when one of them, reading a newspaper, announces that "Ivan Ilyich is dead" (Cook 2004: 79). The immediate thoughts of those present are filled with what effect his death may have on their existing positions, in that the resulting vacant position could open up opportunities for promotions.

The behavior of the mourners at Ivan's funeral illustrates the futility of his life. As well as his legal colleagues' preoccupation with possible promotions, his wife is asking for advice regarding monetary gains from her pension due to her husband's death. His friend and associate is thinking about a bridge game planned for that evening:

... this incident of a church service for Ivan Ilyich could not be a sufficient reason for infringing the order of the session - in other words, that it would certainly not prevent his unwrapping a new pack of cards and shuffling them that evening while a footman placed fresh candles on the table: in fact there was no reason for supposing that this incident would hinder their spending the evening agreeably (Cook 2004: 82).

There is a pervading atmosphere of pretension, with the mourners feigning grief for appearances sake and entertaining thoughts of their own selfish concerns. Through the coldly detached narrator Tolstoy cleverly mirrors aspects of Ivan's behavior during his life. An interaction between Ivan's wife, Praskovya Fyodorovna, and Ivan's best friend, Pyotr Ivanovich, indicates this preoccupation with correctness in "doing the right thing":

Praskovya Fyodorovna, recognising Pyotr Ivanovich, sighed, went right up to him took his hand, and said: "I know you were a true friend of Ivan Illyich's ..." and looked at him, expecting from him the suitable action in response to these words. Pyotr Ivanivich knew that, just as before he had to cross himself, now what he had to do was to press her hand, to sigh and to say, "Ah, I was indeed!" And as he did so, he 
felt that the desired result had been attained; that he was touched, and she was touched (Cook 2004: 82-83).

There is not at any point a sense of grief, with the exception of Ivan's tear stained son who quietly and morosely enters the story, in contrast to the rest of the characters: "from the staircase there appeared the figure of the son ... his eyes were red with crying" (Cook 2004: 85-86). As the extract shows, Tolstoy is not explicitly saying that the attitude of the mourners highlight aspects of Ivan's life, he shows this indirectly through his characters, in a similar way to Chekhov.

To continue the story the narrator then, through analepsis, charts the progress of the central character portrayed as a self-absorbed individual in which professional, social and material gains are the main concern of his existence. Ivan Ilyich graduates from law school and then works his way up to examining magistrate to finally securing a position as a member of the judicial council. He is consistently over-concerned with keeping up appearances, not only to satisfy and please his superiors, when rising up the ranks, but at the same time to maintain a parallel social position with what he considers to be the best people. His behavior is marked by a punctilious concern with correctness and decorum with the sole aim of maintaining a prestigious image professionally and in society. In his married life too he is concerned about giving the right impression that could give him: "above all, that perfect propriety in external observances required by public opinion" (Cook 2004: 92).

Ivan, after moving to another town to take up his final position, obsessively decorates and furnishes the rooms of his new apartment in order to make sure that it is in line with what anyone in such a position would be expected to have. The following extract from the story shows the obsession that ultimately leads to his downfall:

Ivan Ilyich himself looked after the furnishing of them, chose the wallpapers, bought furniture, by preference antique furniture ... and it all grew up ... and really attained the ideal he had set before himself ... his arrangement surpassed his own expectations ... elegant and free from vulgarity ... he could see the hearth, the screen, the etagere and the little chairs dotted here and there ... the plates and dishes on the wall, and the bronzes as they would be when they were all put in their places. He was particularly successful in coming across and buying cheap old pieces of furniture, which gave a peculiarly aristocratic air to the whole (Cook 2004: 96).

He insists on climbing a ladder to hang the curtains himself, to make absolutely sure that they will be draped in just the right way. As a result he falls off the ladder knocking his side against the corner of a frame and bruising himself rather badly, which is the start of his debilitating illness.

This is the transition point between Ivan's pinnacle of success, professionally and socially and the start of the deterioration through his illness. But, rare in Tolstoy, there is no commentary about the dangers of this unwise preoccupation leading to Ivan's demise, this continues to remain unsaid. Marcella Bertuccelli, in her essay on implicitness, writes: 
The power of literary expression is such as to allow a potentially unlimited number of interpretations; then there must be something in the underlying meaning which is never made totally and definitely explicit. Language is actualised in literary texts, but literary texts turn out to be complex inferential mechanisms ... (Bertuccelli 2003: 17-18).

In her essay Bertuccelli continues to discuss the "unsaid" in an analysis of James Joyce's short story Araby. Her observations here are relevant to the nature of the unsaid in The Death of Ivan Ilyich, in terms of the narrative being "rich in meanings of universal significance" (Bertuccelli 2003: 20) that can be fleshed out by the reader in order to bring the unsaid to conscious awareness:

But our interest here is not so much on the story which is narrated, as on the story that is left unsaid, which is hidden in the halo of implicit meanings that I have defined as the "implicitude" of the text ... There are numerous points in the narrative where we become aware of the unsaid ... (Bertuccelli 2003: 20).

A few noteworthy examples from Tolstoy's story that give the reader an opportunity to experience an awareness of the unsaid, are: the immediate response of Ivan's colleagues at hearing of his death; the attitude of the mourners at his funeral; Ivan's preoccupation with keeping up an image befitting to his status; his obsession with furnishing his new apartment to keep up appearances. These are the points at which the reader is invited to engage with the real meaning of the story.

It is this consistent "implicitude" of the narrative, along with the "single effect" and "intensity of impact" that makes this a long story with substantial short story features, despite the extensive external detail and omniscient narrator.

In the following extract James Lasdun makes a comparison between Tolstoy's tendency to foreground grandeur in his writing, to Chekhov's elusive and reticent style:

To think of Tolstoy is to conjure, at once, the note of impassive grandeur, as of creation being set out in glittering ranks for inspection. Anton Chekhov, whose short career was as momentous .... has his own distinct tone and manner, but the impression it leaves is curiously elusive, offering reticence and hesitation in place of "personality", and a series of moods rather than a discernable attitude to life, even the attitude of uncertainty ... (Lasdun 2010: ix).

The Death of Ivan Ilyich deviates from this view of Tolstoy's writing generally, as this story is far from grand in any aspect. After the story's opening, depicting the aftermath of Ivan's death and then at the beginning of the analepsis to Ivan's previous life, the oft quoted statement: "The previous history of Ivan Ilyich was the simplest, the most ordinary, and the most awful" (Cook 2004: 86) gives a foreshadowing of the story to come, with the expectation that the portrayal of Ivan's life as false, empty and loveless could possibly lead to an inevitable, unpleasant end, which is another trigger point for fleshing out the unsaid. Referring to this Freeborn explains that: 
It is terrible partly because the simple, ordinary surface of his life - career, relationships, the things which fill it - seem to conceal a thinly disguised layer of satire ... Gradually this layer peels away to reveal the true horror beneath it ... (Freeborn 2002: 128-129).

The Grasshopper, was one of Tolstoy's favourite Chekhov stories. He was not only impressed with the story; he also considered it to be one of his best works. There are similarities in terms of content between the two stories in that the main character, Olga Ivanovna, is deeply concerned with creating the right impression, albeit for a different motivation. She is obsessed with celebrity and spends her life seeking it by gathering around her those in the artistic world whom she considers to be "great" and of celebrity status. This is not only to ensure reflected glory but also with the deluded aim of attaining greatness for herself through her own artistic endeavours, via her association with celebrity.

As a result she experiences eventual despairing unhappiness due to living a self-centred and self-absorbed lifestyle that leads not to her own death but that of her doctor husband, Osip Dymov. She considers him to be sweet natured but at the same time she sees him as most dull and ordinary and although she superficially adores Dymov, she places him on the margins of her life favouring those who she considers to be more exciting and significant, particularly the flamboyant landscape artist Ryabovsky.

Later in the story, Olga is alone with Ryabovsky on a trip down the Volga. She is clouded with passion for him and tempted by his assertions of love for her, she thinks of Dymov: "What did she care about Dymov? ... For so simple, so very ordinary a man the happiness which he has already received is quite adequate ..." (Lasdun 2010: 154).

Olga sees too late, however, the possibility that her behavior could have been the cause of considerable anguish to her husband; with the implication that this led to his premature death. I say implication because it is not stated directly that her behavior was the indirect cause. Indeed it is noted in the narrative that her husband contracted diphtheria through sucking some diphtherial membrane from a boy's throat, through a tube, but as Donald Rayfield notes:

The Grasshopper is a satirical portrayal of a woman ... who lives on reflected glory and jumps from one celebrity to another in search of it ... But in contrast to the satire, a morality story is in progress. Olga frivolously marries a saintly doctor and by her trivial explorations, her adultery with an artist and her lies, drive him to despondency, so that overworked and careless, he infects himself with diphtheria (Rayfield 1999: 100).

Virginia Woolf admired Chekhov's treatment of complex emotions in his characters, "... full of a nondescript melancholy, of discomfort, of queer relationships which beget emotions that are half ludicrous and yet painful" (Rubenstein 2009: 61) and especially that he was able to effectively convey this in very brief narratives.

The Grasshopper is a relevant example of this, because although Olga's highly charged emotions appear to be ludicrous and misguided she continues in 
her deception to live a life that is actually a fantasy without any awareness of either reality or a sensitivity to the feelings of others, particularly her husband. It is painful to see her pursuing a false life with people, all men, who just reinforce her belief that they are great and that she too, is heading for greatness. This is her deception.

Where this differs from Tolstoy's story is the treatment of the parallel characters, Ivan and Olga. Ivan is vividly explicated, every aspect of his life and demise is noted in minute detail. The step by step details of his developing illness shows how each sign and symptom absorbed him exclusively, developing into an introspection that dominated his entire waking hours, constantly analysing the sequence of events that led up to it and questioning, why?

"Resistance is impossible" he said to himself. "but if one could at least comprehend what it's for? Even that's impossible. It could be explained if one were to say that I hadn't lived as I ought. But that can't be alleged", ... thinking of all the regularity, correctness, and propriety of his life. "That really can't be admitted" ... "No explanation! Agony, death ... What for?" (Cook 2004: 126).

The intensity of impact takes the reader along with Ivan in his sufferings, resulting in him becoming a sympathetic character, especially with the introduction of Gerasim, a healthy and vigorous peasant servant who is the only person who has the effect of soothing him by his natural and easy manner. The presence of Gerasim, cheerful and natural in his behavior has this effect on him because he was the only one who did not keep up the deception that Ivan believed that everyone else, including the doctors, maintained so as not to reveal any unpleasant truths to him, "... that he was simply ill, and not dying and that he need only keep quiet and follow the doctors orders, and then some great change for the better would be the result" (Cook 2004: 115). Gerasim was realistic, with a manner that was neither harsh nor false. He would say to Ivan, "We shall all die. So what's a little trouble" (Cook 2004:115) after Ivan expresses concern for Gerasim spending entire nights supporting his legs to help relieve the pain. But as soon as a colleague visits him he quickly returns to the severe demeanor of his past:

Tolstoy's enduring belief that the peasantry's uncomplicated faith and stoical acceptance of whatever life inflicted on them were vastly preferable to the sophisticated insincerities, decadent materialism and "perfected proprieties" of the society into which he was born. Ilyich's constricting sense of decorum is such that, though he accepts Gerasim's care and longs "to be petted, kissed and wept over", when a colleague comes in, he reverts to the severe businesslike persona appropriate to a judge (Cook 2004: xviii).

This imperious demeanor ironically comes right back to Ivan via the attending doctor, so he is at the receiving end of the same severe attitude that he always gave to his subordinates, or to anyone not at the same level as him at work or in society, as this extract from Freeborn's essay shows:

... the detailed description of the material surroundings of his life underlines its pettiness while emphasising the isolating, introspective process of his growing 
sickness. He consults a doctor and ironically receives the same lordly rebuttal of his concerns as he himself is accustomed to giving to plaintiffs in his courtroom (Freeborn 2002:129).

Whereas in The Grasshopper, Olga, despite being the dominant consciousness in the story, is not sharply drawn as Ivan is, rather, she flits from situation to situation in a butterfly like manner enveloped in an aura of selfindulgence that distances her as a character.

Chekhov's technique of using the landscape to reflect a character's mood intensifies this distancing effect as it is an indirect reference, but at the same time has the effect of bringing the character's deepest feelings to the fore. His descriptions of nature are not just an indulgence in embellishments, but are carefully included to enhance and therefore reinforce the mood of the character:

... this mirroring of a character's mood in nature, which is coloured by his whole outlook, is characteristic of Chekhov and is achieved so subtly that it never appears as any contrived seeking after effect (Wilks 1982: 11).

The following two extracts are examples of Chekhov's device of reflecting a character's mood in nature. He uses contrasting descriptions of nature to reflect the opposing moods of the character. Olga is sailing on the Volga with her artist friends and it is the eve of her affair with Ryabovsky who she considers to be "a truly great man, a genius, one of God's elect" (Lasdun 2010: 153). Olga is infatuated with him and as she is standing beside him by the ship's rail she observes the scene before her:

"Turquoise-hued water such as she had never seen before, sky, banks, black shadows, mysterious joy flooding her innermost being" (Lasdun 2010:153).

But when the brief affair soured, she experienced quite a different scene. In this passage Chekhov effectively conveys Olga's unhappiness with Ryabovsky's indifference towards her, after so short a time:

No longer did the river glisten. It was dim and lusterless, it had a cold look to it. Everything around seemed to presage a melancholy, gloomy autumn. Sumptuous, green-carpeted banks, brilliantly reflected sunbeams, translucent blue distance ... nature seemed to have taken everything showy and flamboyant from the Volga and packed it away ... while crows flew about the river taunting its nakedness with their raucous caws (Lasdun 2010:155).

Olga does not develop into a sympathetic character, even later in the story when she realises that Dymov is seriously ill and she is distraught after hearing one of the attending doctors call out,

"He's sinking ... What a loss to science ... compared to the rest of us he was a great man ... outstanding. What gifts!"

"What hopes we all had for him" Korostelyov continued, wringing his hands. ...

"He was a real scientist - you don’t find his sort anymore" (Lasdun 2010: 167). 
It appears that Olga is mainly feeling sorry for herself, especially when the awareness arises in her that she is too late to tell him how wrong she had been and that she would, from now on, esteem him as a great man:

She wanted to tell him that there had been a mistake, that all was not yet lost, that life could still be wonderfully happy, that he was a rare, an outstanding, a great man - and that she would worship him all her life, adore him, revere him and do him homage (Lasdun 2010: 168).

This suggests that she is not changed by the experience of her husband's death, but rather mourning the fact that she has lost her chance of being married to a truly great person. The seeking of such an association that she spent most of her life trying to attain. Tobias Wolff points out Chekhov's tendency to avoid the rounded out "happy ending" in his stories:

He did not seek to reassure the reader by forcing his stories to uplifting conclusions, or by firing improbable insights and resolutions into the heads of his characters ... "Man will become better" Chekhov wrote, "when you show him what he is like" (Woolf 1988: xv).

Chekhov was sometimes criticised for writing shapeless stories, "all middle like a tortoise" as John Galsworthy put it (Wolff 1988: xiv). But even though his stories are neither plotted, nor structured with a conventional beginning, middle and end, meaning is present for the reader to work out through implication and indirection. Woolf explains that: "... he arrived at his method not by inadvertence but by the most unsparing, rigorous calculation" (Wolff 1988: xiv).

In his biography of Chekhov, Ivan Bunin refers to the absence of plot in his stories. He quotes Chekhov:

One does not need plots (for stories) for in reality, such things do not exist. Everything is mixed up in life, the profound and the trifling, the great and the insignificant, the tragic and the comic (Bunin 2007: 126).

It is interesting to note here that this is also true of Tolstoy's story in that there is nothing in the narrative that is plotted or superfluous to the intention, despite the considerable explication. The detail is carefully thought out in order to achieve the desired effect with each word carefully chosen as relevant to the whole. in this Tolstoy achieves brevity as there is no digression from the focus of the "single effect" to distract the reader into other avenues.

In contrast to Tolstoy's detail, although achieving the same effect, May notes Chekhov's treatment of his characters and impressionistic atmosphere of his stories:

The primary characteristics ... are characters as mood rather than as either symbolic projection or realistic depiction; story as minimal lyricized sketch rather than as elaborately plotted tale; atmosphere as an ambiguous mixture of both external details and psychic projections; and a basic impressionistic apprehension of reality ... (May 1994: 199). 
This is evident in "The Grasshopper" with both the setting and the characters. Osip Dymov is very much a background figure, realised only through indirection via Olga's references to him. He occasionally appears in the story, as in this following extract when Olga is entertaining her artist friends, as usual, on Wednesdays:

Dymov would not be in the drawing room, nor would anyone remember his existence. But at exactly half past eleven the dining room door would open and he would appear; smiling his good natured, gentle smile. "Supper is served, gentlemen", he would say, rubbing his hands (Lasdun 2010: 149).

Olga treated him like a much loved pet dog. She responds to this announcement by saying to everyone:

My dear ... You're too, too, adorable! Look at that forehead gentlemen ... See gentlemen: the face of a Bengal tiger, but a kindly, charming expression like a fawn. Now isn't he perfectly sweet? (Lasdun 2010: 149).

In The Death of Ivan Ilyich Tolstoy's use of explicitness to convey meaning is potent, but at the same time the implicit dimension, regarding Ivan's lifestyle leading to his death, is not referred to until the end of the story. This is not, however, explicitly revealed but rather suggested through some realisation on the part of Ivan who starts to wonder, as he looks around the room he so carefully planned, if his past behavior could possibly have anything to do with his current dire situation:

But however much he pondered, he could not find an answer. And whenever the idea struck him, as it often did, that it all came of his never having lived as he ought, he thought of all the correctness of his life and dismissed this strange idea (Cook 2004: 124).

The last moments before his death show that although he still cannot quite equate the two as being connected he does nevertheless find some possible reasoning for the extreme suffering he has experienced up to this point, with the possibility that it was that, that caused his illness and demise, and although too late to do anything about it there was a kind of epiphany that gave him some semblance of peace seconds before he died,

... he tries, even at the point of death, to deny that all his life he has been in the wrong. Only at the last minute does he give up fighting, symbolically "seeing the light" at the moment when his grief-stricken son's hand touches him ... he is able to become a complete human being and surrender to his own mortality ... (Cook 2004: xix).

Olga, on the other hand, although realising too late that the trivialities of her life had blinded her to what really mattered, did not die. It was her husband who died and she was left to continue living knowing that she had lost her 
opportunity to live with a truly great and extraordinary man, a celebrity in medical circles.

The irony was that for all Olga's searching after celebrity and reflected glory, she did not at any time realise that she had this in her husband. Her assessment of him as ordinary, sweet, unremarkable was entirely mistaken and this is what Chekhov throws into the story nearing the conclusion.

A classic Chekhovian ending to the story. Nothing resolved or commented on, just the sad realisation that Olga would not change or grow in any way from the experience. Chekhov does not give way to sentimentality or emotional indulgence, he just sets the situation forth as it is, but without judgment.

There is here a quality of mind that is always in Chekhov, controlling his emotions so that he does not bathe in the thing, but condemns it all the while he writes of it ... an approach that is uniquely his own (O'Faolaine 1948: 77).

Chekhov enters a situation, a life, in medias res. He then steps out again without resolution. His endings have a feeling of continuance. His focus is on the present situation, without digression from the main point. The ending usually denotes the end of a particular stage of a situation, not a conclusion about what might happen next.

In Tolstoy's story, there is a definite ending:

"It is over!" someone said over him.

He caught those words and repeated them in his soul.

"Death is over", he said to himself. "It's no more".

He drew in a breath, stopped midway in the breath, stretched and died (Cook 2004: 130).

In The Grasshopper the ending implies continuance on the part of Olga and then a matter of fact practical instruction to the maid from the attending doctor:

"Dymov! She called, feeling his shoulder, unable to believe that he would never wake again. "Dymov!" Answer me, Dymov!"

In the drawing room, Korostelyov was speaking to the maid.

"It's perfectly simple. Go to the church lodge and ask for the almshouse women. They'll wash the body, they'll lay it out and do whatever needs doing" (Lasdun 2010: 168).

\section{Conclusion}

The distinctive differences in the writing styles and narrative techniques of the two authors are explored, in terms of how they come into contact with each other in creating the form of the short story. Despite the contrasting individuality in the writers' literary styles they both demonstrate with equal effectiveness that implicitness and explicitness can weave around one another to shape the story and to allow, as Bertuccelli puts it: "for a recovery of an explicit representation ... involving the two basic processes of fleshing out and filling in" (Bertuccelli 2003: 18). 
The paper aims to show that the two styles achieve the same outcome, in terms of the crafting of a short story with a central single focus, and even more remarkable that Tolstoy manages to achieve this by covering a span of several decades in the life of Ivan Ilyich by starting with Ivan's death, and then by working backwards to chart his life that inevitably leads to his untimely death. The story comes full circle giving a sense of continuum that blurs the dividing line between past and present. In this, The Death of Ivan Ilyich achieves a sense of the moment in a unified narrative despite the passing of years and complexity of the situation.

Chekhov achieves the same outcome, in terms of the crafting of a short story, in a very different way. In The Grasshopper he distances himself, as author, from the main characters, Olga and Dymov, allowing the reader to decide for themselves what the underlying meaning is, the moral of the story, if you like. Chekhov does not make any judgment on the characters' actions, or non-actions, he simply tells the story as it is, without introduction, embellishment or conclusion.

Both writers achieve the "single effect" in different ways. Tolstoy is totally focused on how the life of Ivan Ilyich leads to his early death, without digression or commentary on the moral of the story or elaborating on other details. This is a significant feature of this particular story because in his writings Tolstoy tends to diverge into different avenues in order to share a moral message or other details about his characters, landscape or place. As Vladimir Nabokov puts it: "... the same robust shoulder pushing up a cloud of visions or a load of ideas ... the man who gloated over the beauty of the black earth, white flesh, blue snow, green fields purple thunderclouds ..." (Nabokov 1981: 140).

Chekhov achieves the "single effect" in "The Grasshopper", as in all his stories, by consistently focusing on the situation at hand without deviation and by maintaining economy of description in characterisation, landscape and place. He achieves vivid detail through a single brushstroke, rather than through an expanded descriptive image and these images are further enhanced within an impressionist context that has the effect of intensifying atmosphere: in Nabokov's words, by "being suffused and surrounded by a faintly iridescent verbal haziness" (Nabokov 1981: 253). Even Chekhov's use of landscape to reflect a character's emotions is not sharply drawn. This technique is utilized solely for bringing to the fore the deep feelings of the character and at the same time shows how a particular scene can be an entirely opposite experience visually, according to the character's mood.

There is an absence of landscape in The Death of Ivan Ilyich but Tolstoy's meticulous descriptions of the interior of the apartment Ivan is in, before and during his illness, has the effect of emphasising his preoccupation with making an impression and later in highlighting the torments that Ivan is suffering through his illness. Again, this is unusual for Tolstoy as his detailed descriptions of interior and outdoor spaces can often develop into a separate experience from any aspect of the story, rather than for the purpose of enriching a characters mood or circumstance. 
The form of the short story is multifaceted and this study does not cover every aspect of narrative technique for this form, but I have attempted to introduce some new thought into the short story debate, that it is possible to have two writers as diverse as Tolstoy and Chekhov create stories with contrasting narrative techniques that ultimately achieve the same outcome without development into a cumulative narrative, characteristic of the novel form.

\section{References}

Barger A (Ed.) (2009) Leo Tolstoy's 20 Greatest Short Stories. US/UK: Bottletree Books, LLC.

Bertuccelli PM (2003) The Unsaid in Joyce's "Araby": A Linguistic Perspective. Journal of the Short Story in English 40: 17-28.

Bunin I (2007) About Chekhov: The Unfinished Symphony (Eds.) Thomas Gaiton Marullo. Illinois, USA: Northwestern University Press.

Cook TCB (Ed.) (2004) The Death of Ivan Illyich and Other Stories: Leo Tolstoy. Ware, Hertfordshire: Wordsworth Editions Limited.

Freeborn R (2002) "The Long Short Story in Tolstoy's Fiction." In DT Orwin (Eds.), The Cambridge Companion to Tolstoy. Cambridge: Cambridge University Press.

Harrison M (2018) "A Daring Debut Collection Explores Alienation, Absurdity and the Things that are Left Unsaid" (Mothers by Chris Powers). The Guardian Review. London, UK: Guardian Media Group plc/Scott Trust Ltd.

Lasdun J (Ed.) (2010) Anton Chekhov: The Collected Stories, Volume 2. London: The Folio Society.

May CE (2002) The Short Story: The Reality of Artifice. New York and London: Routledge.

May CE (Ed.) (1994) "Chekhov and the Modern Short Story". In The New Short Story Theories. Athens, Ohio: Ohio University Press.

McVay G (Ed.) (2001) Anton Chekhov Short Stories. London: The Folio Society.

Nabakov V (1981) Lectures on Russian Literature. Orlando, Florida: Harcourt Inc.

O'Connor F (2003) The Lonely Voice: a Study of the Short Story. Cork City, Ireland: Cork City Council.

O'Faolain S (1948) The Short Story. London: Collins.

Poe EA (2003) "Philosophy of Composition (1846)". In D Galloway (Eds.), Edgar Allan Poe: The Fall of the House of Usher and Other Writings. London: Penguin.

Rayfield D (1999) Understanding Chekhov: A Critical Study of Chekhov's Prose and Drama. Madison, Wisconsin: The University of Wisconsin Press.

Rubenstein R (2009) Virginia Woolf and The Russian Point of View. New York: Palgrave Macmillan.

Wilks R (Ed.) (1982) Anton Chekhov: The Kiss and Other Stories. London: Penguin.

Woolf T (Ed.) (1988) A Doctor's Visit: Short Stories by Anton Chekhov. New York: Bantam Books. 
